\title{
THE EFFECT OF HYPNOTHERAPY ON PRIMARY DISMENORE IN ADOLESCENTS
}

\author{
Hemi Fitriani ${ }^{1}$, Achmad ${ }^{2}$ \\ ${ }^{1,2}$ Stikes Jenderal Achmad Yani Cimahi, Cimahi, Indonesia \\ Correspondence: hemi.ftrn@yahoo.com
}

\begin{abstract}
The health problem that often threatens of young women in the puberty period is dysmenorrhea. The survey revealed that 54.89\% of adolescents ages 14-19 years in Indonesia experience dysmenorrhea in 2011. Dysmenorrhea would be impacted in adolescents' daily activities including g unable to take part in activities at school, lacking concentration and finally disrupting adolescent achievement. Dysmenorrhea requires proper and effective treatment so that adolescents will maintain and improve their health. This study aimed to determine the effect of hypnotherapy on the primary adolescent dysmenorrhea. The research that was a Quasi-Experiment study, with the design of the Non-equivalent Control Group. The research sample consisted of 13 students taken by purposive sampling. The Numeric Rating Scale (NRS) used for data collection. The univariate analysis applied to analyze the median, and bivariate analysis used the Mann Whitney test. Statistically, the study obtained pValue $=0.018$, there was a significant effect of hypnotherapy on decreasing primary dysmenorrhea. Health workers may use hypnotherapy as an alternative intervention to overcome primary dysmenorrhea in adolescents.
\end{abstract}

Keywords: Adolescence, hypnotherapy, primary dysmenorrhea.

\section{INTRODUCTION}

The health problem that is often experienced by young women is dysmenorrhea. Mahmudiono (2011) stated that $54.89 \%$ of adolescents aged 14-19 years had dysmenorrhea problems in Indonesia in 2011. The incidence of dysmenorrhea in Indonesia is quite high. This is illustrated by the results of several studies in the Indonesian region, including in the village of Banjar Kemantren, there were $71 \%$ of women of childbearing age experiencing dysmenorrhea (Novia \& Puspitasari, 2013). There are no definite figures regarding the number of dysmenorrhea in West Java. Symptoms of dysmenorrhea would interfere with teenagers' daily activities (Rohmawati, 2014). Symptoms of dysmenorrhea include abdominal pain or abdominal cramps spreading to the waist accompanied by fatigue, nausea, vomiting, headaches, and diarrhea. Saguni, Madianung \& Masi (2013) stated that a student who has dysmenorrhea cannot concentrate on learning and motivation to learn will decrease because dysmenorrhea is felt during the teaching and learning process, which will disrupt the learning achievement of adolescents. 
Hemi Fitriani: The Effect of Hypnotherapy on Primary Dismenore In Adolescents

Handling dysmenorrhea known by the public is pharmacological treatment, but this treatment was less attractive to teenagers because of the concerns about the side effects of the drug. Non-pharmacological treatment is more in demand. Non-pharmacological treatment of dysmenorrhea can be done with warm compresses, massage, yoga, hypnotherapy and progressive muscle relaxation (Boba et all, 2005). Of the several non-pharmacological alternatives, the most practical treatment to do is progressive muscle relaxation and hypnotherapy, because it does not require tools, and can be done in all conditions. This study aimed to determine the effect of hypnotherapy on the primary dysmenorrhea in the adolescent.

\section{METHODS}

This study applied the Quasi-Experiment approach. The population in this study were all X grade students of Cimahi public high school 4 who had experienced menstrual period, maximally two years calculated from the age of menarche, and experienced dysmenorrhea during menstruation. 91 female students were identified as having dysmenorrhea. Sampling is done by using purposive sampling technique. Sugiono (2009) said that the sample limit for simple experiments was between ten and twenty people, in this study the researchers took thirteen female students who experienced dysmenorrhea as the study sample. The sample inclusion criteria included female students who were dysmenorrhea at the time of the study, dysmenorrhea occurred the first day of menstruation, there were no previous pharmacological and nonpharmacological treatments, a positive test of hypnotherapy was performed. Exclusion criteria included female students who had a gynecological disease or secondary dysmenorrhea and female students who were absent. Data collection was done by filling out the Numeric Rating Scale (NRS) questionnaire before and after the intervention. The research 
instrument is explained in chart one. The researcher did not test the validity and reliability of the instrument because the validity had been tested by the previous study.

Data were analyzed using tendency central (median) for univariate analysis, while for bivariate analysis with the non-parametric test, namely Mann Whitney test because the results of normality test showed the data were not normal (Riyanto, 2011). The research applied the principle of research ethics, namely respect for the person, and justice. The application of ethical principles is to provide an explanation of the purpose and implementation of research to respondents. Respondents were given an explanation that this respondents' participation was voluntary. Respondents who decided to take part in the study then asked for written approval for Informed consent. All respondents received the same treatments. The location of this research was conducted at Cimahi Public High School 4. Data collection is carried out from July to September 2016.

\section{RESULTS}

Table 1 describes the pain scale of dysmenorrhea before and after interventioniin detail from the intervention group.

Table 1. Differences in The Pain Before and After Intervention in The Intervention Group

\begin{tabular}{llcccc}
\hline Variable & Measurement & Median & SD & SE & $\begin{array}{c}p- \\
\text { Value }\end{array}$ \\
\hline Pain & Before & 3 & 1,472 & 0,408 & 0,002 \\
& After & 0 & 1,092 & 0,303 & \\
\hline
\end{tabular}

Table 1 illustrates that there was a decrease in the median of pain in respondents before and after given hypnotherapy. The results of statistical tests using the Wilcoxon test obtained the value of 0.002 , it can be concluded that there was a significant effect of hypnotherapy on the decrease in the scale of dysmenorrhea. 
Hemi Fitriani: The Effect of Hypnotherapy on Primary Dismenore In Adolescents

\section{DISCUSSION}

The results of this study indicate that there is a significant effect of hypnotherapy on decreasing the scale of dysmenorrhea. These results are in accordance with Sidabutar's (2014) study which states that there is the effect of hypnotherapy on dysmenorrhea with a value of 0.0001. Research by Primatama, Zariat, Nugraha \& Adi (2014) also states that hypnotherapy can reduce the scale of dysmenorrhea. The results of this study are in accordance with Gunawan's 2010 statement which states that hypnotherapy is one of the non-pharmacological interventions that can be done to reduce pain.

Hypnotherapy would reduce the intensity of primary dysmenorrhea through two mechanisms. The stage of induction and deepening in hypnotherapy is the first mechanism to reduce the intensity of pain in dysmenorrhea. The induction and deepening stage is the relaxation stage through deep breathing relaxation which aims to make the brain reach theta wave conditions (Benson \& Proctor, 2000; Potter \& Pery, 2006). At the same time, this relaxation condition stimulates the body through the path of the HPA Axis, to produce Corticotropin Releasing Factor (CRF). Furthermore, CRF stimulates the pituitary gland to reduce $\mathrm{ACTH}$ production so that it increases the production of endogenous analgesic, which is endorphin which then decreases the production of cortisol and other stress hormones so that pain decreases (Price \& Wilson, 2006). Endorphin works to suppress pain impulses in the spinal cord, by holding pain impulses in the spinal cord, pain impulses are not delivered to the thalamus and in the end, no pain impulses are channeled to the cerebral cortex (Prasetyo, 2010). The stage of induction and deepening which is the initial stage of hypnotherapy already has a contribution in reducing pain (Wong, Willy \& Hakim, Andri, 2009).

The second mechanism is the suggestion received by the subconscious, it will change the perception of pain in the cerebral cortex. The stage of suggestion in hypnotherapy is an action to provide new data, enter the subconscious mind in the limbic system. The data 
Hemi Fitriani: The Effect of Hypnotherapy on Primary Dismenore In Adolescents

entered is the impulse data from the uterus when contracted which is delivered, and is perceived as a feeling of happiness, and expected feeling. This new data will be stored in the subconscious memory. In a conscious state, the subconscious mind will affect the cerebral cortex, which is to give data according to suggestions. When the cerebral cortex gets an impulse contraction, the impulse will be perceived as a feeling of happiness and gratitude (Purwanto \& Setiyo, 2008). This condition is permanent (Gunawan, 2010). These two mechanisms are explanations that hypnotherapy can reduce pain intensity.

\section{CONCLUSION}

This study concluded that there are significant changes in the scale of dysmenorrhea pain a before hypnotherapy 3.00 with the category of mild pain and after hypnotherapy dropped to 0 with the category of no pain. Health workers, especially nurses in the Public Health Centre who are in charge of UKS (School Health Programs) to implement hypnotherapy interventions in dealing with dysmenorrhea in adolescents, especially adolescents who have positive suggestibility. For nursing institutions, this study finding can be used as a source of teaching material in maternity nursing subjects, more specifically menstrual disorders.

\section{ACKNOWLEDGMENT}

Thank you to the Ristekdikti for funding this research. Thank you also to Stikes General Achmad Yani who facilitated in obtaining research funding from Ristekdikti

\section{REFERENCES}

Ariyani, Ni Putu. (2007). Terapi Modalitas Keperawatan. Universitas Indonesia. Arter, Derry .(2014). Hypnotic Power. Yogyakarta : Mantra Books. 
Hemi Fitriani: The Effect of Hypnotherapy on Primary Dismenore In Adolescents

Benjamin \& Virginia. (2013). Buku Ajar Psikiatri Klinis. Jakarta : EGC.

Benson, H \& Proctor, W. (2000). Dasar-dasar respon relaksasi. Bandung:Kaifa

Gunawan, W Adi. (2010). Hypnoterapi The Art Of Subconscious Restructuring. Jakarta : Gramedia.

Mahmudiono, T.(2011). Fiber, PUFA and calcium intake is associated with the degree of primar dysmenorrheal in adolescent girl Surabaya, Indonesia. Journal Obstetrics \& Gynecology.

Nadia, Bianda. (2010). Hipnotis Metode Terapi Anak Dengan Hipnoterapy. Jakarta : Gudang Ilmu.

Novia.I \& Puspitasari. N. (2013). Faktor risiko yang mempengaruhi kejadian dismenore primer. The Indonesian Journal of Public Health; Vol.4, No. 2: 96-104

Potter \& Perry. (2006). Buku Ajar Fundamental Keperawatan Konsep Proses Dan Praktik Edisi 4 Volume 2. Jakarta : EGC.

Prasetyo. (2010). Konsep Dan Proses Keperawatan Nyeri. Yogyakarta : Graha ilmu.

Price \& Wilson. (2006). Patofisiologi Konsep Klinis Proses-Proses Penyakit Edisi 6 Volume 2. Jakarta : EGC.

Primatama, Zariat \& Nugraha, Ardiansyah Adi. (2014). Pengaruh Hipnoterapi Terhadap Penurunan Nilai Visual Analog Scale Pada Dysmenorrhea Di Universitas Muhammadiah Yogyakarta. Tersedia : http://www.thesis.umy.ac.id, diperoleh tanggal 17 Februari 2015.

Purwanto \&Setiyo. (2008). Mengatasi Insomnia Dengan Terapi Relaksasi.Tersedia:http//publikasiilmiah.ums.ac.id diperoleh tanggal 24 Mei 2015. Riyanto (2011). Metodologi Penelitian Kesehatan. Yogyakarta : Nuha Medika 
Hemi Fitriani: The Effect of Hypnotherapy on Primary Dismenore In Adolescents

Rohmawati, Sulis \& Ekawati, Heny. (2014). Perbedaan Pemberian Kompres Hangat Dan Aromatherapy Terhadap Penurunan Nyeri Menstruasi (Dismenore) Pada Siswi Kelas XI SMA Negeri 1 Karang Binangun. 1 (17), 45.

Saguni.F.C.A, Madianung.A, Masi.G. (2013). Hubungan dismenore dengan aktivitas belajar remaja putri di SMA Kristen I tomohon. Ejournal keperawatan (e-Kp) ;Vol 1.No 1

Sidabutar, Jenita. (2014). Pengaruh Hipnoterapi Terhadap Dismenore Primer Pada Siswi SMP Patriot Bangsa Desa Tani Mulya. Skripsi, Cimahi, STIKES jenderal achmad yani.

Smeltzer and Bare. (2013). Buku Ajar Keperawatan Medikal Bedah Vol. 1. Jakarta : EGC.

Sugiono. (2009). Metode Penelitian Bisnis. Bandung : Alfabeta.

Wahida, Nur \& Khusniyah, Zulfa. (2008). Pengaruh Hipnoterapi Terhadap Nyeri Sendi Pada Lansia. Tersedia : http://www.journal.unipdu.ac.id, diperoleh tanggal 17 Februari 2015

Wong, Willy \& Hakim, Andri. (2009). Dahsyatnya Hypnosis. Jakarta : Visi Media. 